\title{
DOŚWIADCZENIA CATHERINE ASHTON WYZWANIEM DLA FEDERICI MOGHERINI
}

\author{
Małgorzata Smutek \\ Wydział Dziennikarstwa i Nauk Politycznych, Uniwersytet Warszawski \\ e-mail: malgorzata.smutek@gmail.com
}

\begin{abstract}
Streszczenie: Celem artykułu jest analiza wyzwań stojących przed Federicą Mogherini jako Wysoką Przedstawiciel Unii do spraw Zagranicznych i Polityki Bezpieczeństwa w relacji do problemów, z jakimi zmierzyła się jej poprzedniczka Catherine Ashton. Omówiono konkretne zadania w ramach WPZiB, którymi Mogherini będzie musiała się zająć, w tym problemy dotyczące sposobu sprawowania funkcji Wysokiego Przedstawiciela. Pozwoli to na określenie charakteru kadencji Mogherini oraz prawdopodobnego kierunku zmian, jakie wprowadzi.
\end{abstract}

Słowa kluczowe: Federica Mogherini, Wysoki Przedstawiciel, Wysoki Przedstawiciel do Spraw Zagranicznych i Polityki Bezpieczeństwa, Wspólna Polityka Zagraniczna i Bezpieczeństwa, Catherine Ashton

\section{WSTĘP}

Celem utworzenia stanowiska Wysokiego Przedstawiciela Unii do spraw Zagranicznych i Polityki Bezpieczeństwa był rozwój wspólnej polityki zagranicznej i bezpieczeństwa oraz wzmocnienie pozycji Unii Europejskiej na arenie międzynarodowej. Takie też idee przyświecały państwom członkowskim podczas reformy tej funkcji w ramach Traktatu z Lizbony. Pierwszą osobą, która sprawowała urząd Wysokiego Przedstawiciela zgodnie z nowymi przepisami była Brytyjka - Catherine Ashton. Jej pracę oceniano bardzo negatywnie, zarzucano jej wręcz, że nie rozumie powierzonego jej zadania [Quatremer 2010]. Można więc przypuszczać, że poszukując nowej kandydatki na to stanowisko i wybierając Włoszkę Federicę Mogherini, państwa członkowskie widziały w niej osobę obdarzoną cechami, których brakowało jej poprzedniczce, a jednocześnie oczekiwały, że zadania Wysokiego Przedstawiciela będą teraz wykonywane bez przeszkód na bardzo wysokim poziomie.

Oczekiwania wobec Wysokiego Przedstawiciela są ogromne, a często wręcz nierealne, o czym przekonała się C. Ashton wraz z objęciem tego stanowiska w li- 
stopadzie 2009 roku. Będąca raczej sumienną urzędniczką i zdolną organizatorką niż charyzmatyczną polityk Brytyjka od samego początku była krytykowana za zbyt zachowawczą postawę oraz unikanie mediów. Zarzucano jej ponadto całkowity brak inicjatywy i brak znajomości zasad rządzących światem dyplomacji. Ta miażdżąca krytyka może dziwić, zwłaszcza że od początku było wiadomo, iż C. Ashton, mimo bardzo bogatego doświadczenia $\mathrm{z}$ wielu dziedzin, nigdy nie zajmowała się polityką zagraniczną ani kwestiami bezpieczeństwa międzynarodowego. Nie posiadała również charyzmy ani osobowości, by stać się politykiem rozpoznawalnym na arenie międzynarodowej i liczącym się w dyskusjach nad sprawami polityki zagranicznej.

Mimo to C. Ashton znalazła „swoje miejsce” w ramach zadań powierzonych Wysokiemu Przedstawicielowi. Swoją skrupulatność i wytrwałość wykorzystała, prowadząc długie i żmudne negocjacje oraz mediacje. Właśnie na tym polu osiągnęła największe sukcesy, najpierw doprowadzając do tymczasowego porozumienia w rozmowach w sprawie irańskiego programu nuklearnego, potem do podpisania pierwszej umowy dotyczącej zasad normalizacji stosunków między Serbią i Kosowem. Do niewątpliwych sukcesów C. Ashton należy również zaliczyć zorganizowanie Europejskiej Służby Działań Zewnętrznych, co było jednym z jej głównych zadań. Mimo to jej kadencję uważano za nieudaną, a samą C. Ashton krytykowano za sposób, w jaki wykonywała powierzoną jej funkcję. Zarzucano jej brak inicjatywy, opieszałość i, o czym już wspomniano, obsesyjne wręcz unikanie mediów.

Stąd też można założyć, że dokonując ponownego wyboru na stanowisko Wysokiego Przedstawiciela, państwa członkowskie szukały osoby, która odznaczałaby się cechami, jakich brakowało C. Ashton. Federica Mogherini była z pewnością lepiej przygotowana do powierzonego jej zadania, zarówno jeśli chodzi o wykształcenie z zakresu nauki o polityce, jak i doświadczenie w sprawach polityki zagranicznej i bezpieczeństwa. W przeciwieństwie do swej poprzedniczki była aktywnym politykiem i zajmowała stanowiska pochodzące z wyborów powszechnych, m.in. zasiadała we włoskim parlamencie. Od roku 2008 była członkiem Włoskiego Instytutu Spraw Zagranicznych, w latach 2008-2013 zasiadała w Zgromadzeniu Parlamentarnym Rady Europy, a potem przez rok przewodniczyła włoskiej delegacji do Zgromadzenia Parlamentarnego NATO. W roku 2014, tuż przed powołaniem na stanowisko Wysokiego Przedstawiciela, została mianowana ministrem spraw zagranicznych i współpracy międzynarodowej Włoch [WWW Komisja Europejska].

Mimo że F. Mogherini wydaje się o wiele lepiej przygotowana do pełnienia funkcji Wysokiego Przedstawiciela niż C. Ashton, także i jej wybór nie może być potraktowany jako radykalne odcięcie się od zachowawczej postawy państw członkowskich przy obsadzaniu unijnych stanowisk. Jak zauważają bowiem komentatorzy polityczni, sześcioletnie doświadczenie Mogherini jako parlamentarzystki i jedynie pół roku pracy w charakterze ministra spraw zagranicznych to niewiele w porównaniu do osiągnięć innych kandydatów na to stanowisko. Ponad- 
to Włoszka w momencie wyboru nie była właściwie znana poza granicami swego kraju i brakowało jej międzynarodowego uznania, które w tej pracy jest bardzo istotne [Redei 2014]. Co więcej F. Mogherini ma opinię unikającej kontrowersji zwolenniczki kompromisów, w czym nie różni się zbytnio od swej poprzedniczki [Manea, Solomon 2014]. Pojawiają się jednak również głosy, że F. Mogherini to właściwy człowiek na właściwym miejscu, jej doświadczenie polityczne nie jest w rzeczywistości takie małe, a ona sama to raczej ,pragmatystka znająca swoje możliwości” [Nünlist 2015].

\section{WYZWANIA DLA WYSOKIEGO PRZEDSTAWICIELA}

Federica Mogherini objęła stanowisko 1 listopada 2014 roku, w momencie gdy Unia Europejska mierzyła się z kilkoma problemami z zakresu WPZiB; były to chociażby: konflikt rosyjsko-ukraiński i wynikające $z$ niego sankcje wobec Rosji, rosnące w siłę tzw. Państwo Islamskie czy problem masowego napływu do UE nielegalnych imigrantów z Afryki, który nie zalicza się wprawdzie do typowego obszaru działań Wysokiego Przedstawiciela, ale dotyka kwestii szeroko rozumianego bezpieczeństwa.

Jedną z kwestii, z którą Wysoka Przedstawiciel będzie musiała się zmierzyć, jest doprowadzenie do dalszych rozmów między Serbią a Kosowem, tym ważniejszą, że dotyczącą bezpośredniego sąsiedztwa Unii Europejskiej i jej ewentualnych przyszłych członków. Przeprowadzenie trudnych negocjacji, których efektem było podpisanie w kwietniu 2013 roku Pierwszej umowy dotyczącej zasad normalizacji stosunków stanowiło jedno z największych dokonań C. Ashton. Jednak wspominany dokument powinien być jedynie pierwszym z wielu koniecznych do uregulowania relacji między oboma państwami. Istnieją zatem uzasadnione oczekiwania wobec nowej Wysokiej Przedstawiciel, by kontynuowała mediacje i wywierała nacisk na Serbię i Kosowo, konieczny nie tylko dla dalszej normalizacji stosunków, ale i zacieśniania współpracy z UE. Oczekuje się chociażby, że Mogherini nakłoni Serbię do wniesienia sankcji wobec Rosji, na wzór wprowadzonych przez Unię Europejską, a tym samym jednoznacznie określi swoje intencje polityczne [Đorđević i in. 2014].

W ciągu pierwszego roku urzędowania F. Mogherini nie uznała kwestii prowadzenia dalszych negocjacji między Serbią a Kosowem za kluczowy element swojej polityki. Świadczy o tym chociażby fakt, że pierwszą wizytę w tych państwach złożyła dopiero pod koniec marca 2015 roku, prawie pół roku po objęciu stanowiska. Być może problemy Bałkanów są jej odległe, a zajmując się w dotychczasowej karierze głównie polityką zagraniczną Włoch, nie poświęcała im wiele uwagi. Niemniej osiągnięcie dalszych porozumień między Serbią a Kosowem mogłoby być stosunkowo łatwym zadaniem dla nowej Wysokiej Przedstawiciel, ponieważ obu państwom zależy na dobrych stosunkach z Unią Europejską, a przede wszystkim na dalszym otrzymywaniu od niej pomocy finansowej. 
Drugim największym sukcesem C. Ashton był przełom w rozmowach na temat programu nuklearnego Iranu [Malantowicz, Smalec 2014]. Długie i żmudne negocjacje w ramach Kwartetu Bliskowschodniego od lat toczyły się bez większych efektów. Funkcję przewodniczącego negocjacji formalnie sprawował Wysoki Przedstawiciel. W listopadzie 2013 roku, dzięki wytrwałości i zaangażowaniu C. Ashton, doszło do podpisania umowy tymczasowej w Genewie. Miała być ona pierwszym krokiem w kierunku ostatecznego unormowania tych kwestii, jednak kolejne tury negocjacji nie przyniosły spodziewanych rezultatów.

F. Mogherini od samego początku zaangażowała się w kontynuowanie negocjacji. Wydaje się też, że tchnęła nowy impuls w przeciągające się rozmowy, gdyż zgodnie z jej zapowiedziami w lipcu 2015 roku podpisano Wspólny Kompleksowy Plan Działań, który stanowi ostateczny krok na drodze do rozwiązania problemu irańskiego programu nuklearnego. Sama zaś Wysoka Przedstawiciel przyznała, że ogromną rolę w osiągnięciu porozumienia odegrał irański minister spraw zagranicznych Mohammad Dżawad Zarif [Mogherini 2015].

Trzecim istotnym wyzwaniem, z którym będzie musiała się zmierzyć F. Mogherini, jest konflikt rosyjsko-ukraiński. Był to ostatni problem, który próbowała rozwiązać C. Ashton, między innymi uczestnicząc w mediacjach i negocjacjach, nieprzestrzeganego później, porozumienia z Mińska. Jest to bardzo złożony problem, który obejmuje wiele aspektów - od kwestii wymiaru ewentualnej pomocy dla Ukrainy, poprzez narastające militarne zagrożenie ze strony Rosji i prowadzenie rozmów pokojowych, aż po ustanawianie bądź też podtrzymywanie sankcji wobec Rosji.

W chwili gdy F. Mogherini obejmowała stanowisko Wysokiego Przedstawiciel, była uważana za przeciwniczkę ,twardej” polityki wobec Rosji; mówiono o niej wręcz, że jest pro-rosyjska [Panichi 2014]. Nie brakowało jednak również głosów, że była to raczej polityka włoskiego rządu niż poglądy samej F. Mogherini [Toscano 2014]. Sytuacja polityczna sprawiła, że kwestie związane z konfliktem rosyjsko-ukraińskim stanowiły pierwsze poważne zadanie dla nowej Wysokiej Przedstawiciel. Niestety było to zadanie, z którym Włoszka sobie nie poradziła. Być może ze względu na słabo ugruntowaną pozycję na arenie międzynarodowej została całkowicie pominięta podczas negocjacji kolejnego porozumienia w Mińsku w lutym 2015 roku. Należy jednak podkreślić, że obawy, iż F. Mogherini będzie zbyt spolegliwa wobec polityki Rosji, okazały się nieuprawnione. Zajęła bowiem stanowisko, że czas rozmów z Federacją Rosyjską już się skończył i konieczne są radykalne środki [EurActive 2014].

Problem konfliktu na Ukrainie nie został rozwiązany i zaczął przybierać formę konfrontacji między Unią Europejską i jej sojusznikami a Federacją Rosyjską. Stąd też będzie to zapewne jedna z kwestii, która pozostanie w agendzie F. Mogherini przez dłuższy czas, bez woli Rosji nie ma bowiem szans na szybkie rozwiązanie. Wysoka Przedstawiciel zapewne nieraz będzie musiała przedstawiać państwom członkowskim konkretne rozwiązania problemu na Ukrainie oraz pogarszających się stosunków z Rosją. 
Innym wyzwaniem stojącym przed nową Wysoką Przedstawiciel jest rozwiązanie problemu masowo napływających na teren Unii Europejskiej imigrantów z Afryki Północnej. Sytuacja ma kilka wymiarów: po pierwsze, moralną odpowiedzialność państw europejskich za los ludzi tonących u ich wybrzeży i konieczność prowadzenia nieustannej akcji ratunkowej na szeroką skalę, po drugie, pojawienie się problemu ogromnej liczby imigrantów mieszkających w obozach dla uchodźców, którzy przybyli do Europy w poszukiwaniu lepszych warunków materialnych, po trzecie, mniej lub bardziej zorganizowaną grupę przemytników, którzy nie zaprzestaną swego niezwykle dochodowego procederu, dopóki będą chętni na ich usługi, po czwarte, duże grupy uchodźców, które przemieszczają się do bogatszych państw Europy.

Problem imigracji, nawet tej nielegalnej, nigdy nie wchodził w zakres kompetencji Wysokiego Przedstawiciela. Jednak w tym przypadku, chociażby ze względu na skalę zjawiska, ta kwestia jest uznawana za zagrożenie dla szeroko rozumianego bezpieczeństwa, które jako element WPZiB realizuje Wysoki Przedstawiciel. Federica Mogherini od samego początku aktywnie zaangażowała się w rozwiązanie tego problemu, być może ze względu na to, że Włochy ponosiły duże koszty związane z napływem imigrantów. Jej zaangażowanie jest o tyle uzasadnione, iż wstępny unijny plan zwalczania nielegalnego przemytu ludzi obejmuje działania zbliżone do tych, jakie zastosowano wobec somalijskich piratów. Jakkolwiek budzą one wątpliwości moralne i nie rozwiązują podstawowego problemu, jakim jest trudna sytuacja w Afryce Północnej, mogą okazać się skuteczne. Zwłaszcza w obliczu determinacji i zaangażowania F. Mogherini. Przynajmniej częściowe rozwiązanie problemu stałego napływu nielegalnych imigrantów może tym samym stać się jednym z jej pierwszych sukcesów na nowym stanowisku. Konieczne jednak będzie również sformułowanie planu rozwiązania sytuacji w Afryce. Także w te działania będzie zapewne zaangażowana Wysoka Przedstawiciel.

$\mathrm{O}$ wiele mniejsze szanse na sukces miałaby F. Mogherini w ewentualnych mediacjach między Izraelem a Palestyną w ramach Bliskowschodniego Procesu Pokojowego. Toczący się od dziesięcioleci konflikt w ostatnim czasie znów się zaostrzył, a wszelkie próby rozmów kończą się fiaskiem. Poprzedniczka Mogherini, C. Ashton, mimo udziału w pracach Kwartetu Bliskowschodniego, nie zaproponowała konkretnych rozwiązań. Z pewnością nie można też powiedzieć, żeby ten aspekt stanowił dla niej priorytetowe zadanie. F. Mogherini wydaje się bardziej zaangażowana $\mathrm{w}$ rozwiązanie problemu. Poproszona przez państwa członkowskie o zaprezentowanie nowej polityki sąsiedztwa wezwała do „świeżego spojrzenia" na konflikt izraelsko-palestyński i zaproponowała powiększenie Kwartetu Bliskowschodniego o państwa arabskie [Nünlist 2015]. Jakiekolwiek kroki zmierzające ku normalizacji stosunków między oboma państwami stanowiłyby niewątpliwie olbrzymi sukces Wysokiej Przedstawiciel, ale szanse na porozumienie są raczej znikome wobec braku woli stron konfliktu.

Innym bardzo ważnym problemem w ramach WPZiB, który pośrednio wiąże się z kwestią wzmożonego napływu nielegalnych imigrantów, jest rosnące w siłę 
Państwo Islamskie. Można zauważyć, że wobec eskalacji innych problemów, zwłaszcza pogarszającej się sytuacji na Ukrainie, kryzysu finansowego w Grecji oraz fali nielegalnych imigrantów, ta kwestia nie stanowiła dla Unii priorytetu. Niewiele mówiło się o ewentualnych próbach reakcji wobec rosnącego zagrożenia ze strony radykalnego Państwa Islamskiego i brakuje wspólnej strategii. Jednak problem narasta i wkrótce nie będzie mógł być dłużej ignorowany, wobec czego Wysoka Przedstawiciel będzie musiała się nim zająć i zaproponować konkretne rozwiązania.

Kolejnym wyzwaniem, zapewne jednym z najtrudniejszych, z jakim mogłaby zmierzyć się F. Mogherini, jest budowa długofalowej strategii w ramach wspólnej polityki zagranicznej i bezpieczeństwa. Dokument, w którym określono by najważniejsze cele w zakresie WPZiB bądź też w ogóle działań zewnętrznych Unii, mógłby stanowić istotny element strategii UE, by stać się ważnym aktorem na arenie międzynarodowej. Poprzednicy Federici Mogherini nie podejmowali prób określenia strategii, a państwa członkowskie nie domagały się działań w tym zakresie. Jednak pod koniec 2013 roku państwa członkowskie udzieliły Wysokiemu Przedstawicielowi mandatu do ponownego określenia priorytetów i interesów Unii w ramach wspólnej polityki zagranicznej oraz dostosowania ich do współczesnych wyzwań. F. Mogherini najwyraźniej postanowiła zająć się tą kwestią; podczas przesłuchania przed Parlamentem Europejskim mówiła o konieczności stworzenia „wielkiej strategii”, „długofalowej wizji” [Nünlist 2015]. Jednak należy pamiętać, że jakiekolwiek działania w tym zakresie wciąż wymagałyby akceptacji ze strony państw członkowskich, które jak dotąd sceptycznie podchodziły do większości pomysłów proponowanych przez Wysokich Przedstawicieli.

Osobną kwestią pozostaje pytanie, czy Unia Europejska w ogóle potrzebuje strategii w ramach WPZiB. Niektórzy badacze uważają, że jest ona całkowicie zbędna, a jej ustalenie mogłoby jedynie ograniczyć swobodę działania UE na arenie międzynarodowej. Pojawiają się również głosy, że paradoksalnie to właśnie brak strategii stanowi „strategię” Unii Europejskiej w ramach WPZiB, pozwalając jej na elastyczność działań, łatwe dostosowanie się do zmiennej sytuacji międzynarodowej i określanie priorytetów w stosunku do relacji z poszczególnymi obszarami geograficznymi.

Innym, być może nawet bardziej kontrowersyjnym obszarem, w którym Federica Mogherini mogłaby się wykazać aktywnością, jest Wspólna Polityka Bezpieczeństwa i Obrony (WPBiO). Przez lata nie było zgody politycznej co do jej kształtu i zasady działania, brakowało również woli, by ją rozwijać. I chociaż pytanie o to, czy Unia Europejska w ogóle powinna posiadać aspekt militarny, jest wciąż aktualne, to wraz z narastającym niepokojem w regionie, a przede wszystkim konfrontacyjną postawą Rosji państwa członkowskie coraz częściej myślą o bezpieczeństwie, także w jego klasycznym rozumieniu.

W budowanie WPBiO włączył się pierwszy w historii Wysoki Przedstawiciel UE ds. WPZiB Javier Solana, który dobrze rozumiał te zagadnienia, jako że wcześniej sprawował funkcję Sekretarza Generalnego NATO. Natomiast Catherine 
Ashton nie miała doświadczenia w tym zakresie i nie poświęcała wiele uwagi sprawom bezpieczeństwa. Mogherini, która posiada znacznie większą wiedzę w tym obszarze, chętniej niż jej poprzedniczka wypowiada się na tematy związane $\mathrm{z}$ bezpieczeństwem i aktywnie uczestniczy w poświęconych mu konferencjach. Być może wspólna polityka bezpieczeństwa i obrony za kadencji Federici Mogherini doczeka się „odświeżenia” i nowych rozwiązań.

Funkcja Wysokiego Przedstawiciela Unii do spraw Zagranicznych i Polityki Bezpieczeństwa, będąc jednym z najwyższych stanowisk w UE, łączy się jednocześnie z olbrzymią odpowiedzialnością i koniecznością sprostania wielu zadaniom. Oczywiście nikt nie oczekuje, że Federica Mogherini odpowie na wszystkie stojące przed nią wyzwania, jednakże to, w jakim stopniu im sprosta i którym poświęci najwięcej czasu i uwagi, będzie rzutowało na przyszłą ocenę jej pracy. Zakres spraw, jakimi może się zająć, jest bardzo duży, tak więc z pewnością wkrótce znajdzie obszar, na którym postanowi się skupić.

\section{SPOSÓB SPRAWOWANIA FUNKCJI WYSOKIEGO PRZEDSTAWICIELA}

Traktat z Lizbony, regulujący kwestie WPZiB, jest niezwykle lakoniczny, gdy chodzi o zasady funkcjonowania stanowiska Wysokiego Przedstawiciela. Poza aspektami formalnymi, takimi jak jego powołanie i odwołanie oraz miejsce w systemie UE, nie określa szczegółowo, w jaki sposób osoba powołana na to stanowisko ma je sprawować. Stąd też duża możliwość indywidualnej interpretacji oraz wykorzystania dotychczasowych doświadczeń kolejnych Wysokich Przedstawicieli i kreowania tego stanowiska zgodnie $\mathrm{z}$ własną wizją.

Jednym z takich aspektów, które nie zostały szczegółowo opisane w Traktacie, jest sposób łączenia stanowisk w ramach tzw. potrójnego umocowania (triple-hatted). Osoba obejmująca stanowisko Wysokiego Przedstawiciela jest jednocześnie wiceprzewodniczącym Komisji Europejskiej (zastępując w obowiązkach dawnego komisarza do spraw zagranicznych) i przewodniczącym Rady do spraw Zagranicznych (stanowisko, które wcześniej należało do ministra spraw zagranicznych państwa sprawującego prezydencję). Na szczególną uwagę zasługuje łączenie stanowisk Wysokiego Przedstawiciela i wiceprzewodniczącego Komisji Europejskiej. Traktat z Lizbony stwierdza jedynie, że Wysoki Przedstawiciel sprawuje funkcję wiceprzewodniczącego o tyle, o ile nie koliduje ona z zadaniami Wysokiego Przedstawiciela. Właściwe ułożenie relacji między Wysokim Przedstawicielem i Komisją Europejską, a przede wszystkim jej przewodniczącym należy do obowiązków tego pierwszego i wpływa na dynamikę jego pracy. Catherine Ashton, której relacje z ówczesnym przewodniczącym Komisji Jose Manuelem Barroso należały do napiętych, rzadko włączała się w prace Komisji.

Oceniając pierwsze działania Federici Mogherini, można zauważyć, że zupełnie inaczej planuje funkcjonowanie na tych stanowiskach. Nie tylko utrzymuje bardzo dobre kontakty z przewodniczącym Komisji Europejskiej Jeanem- 
-Claude'em Junckerem, ale również ściśle współpracuje z innymi komisarzami, przede wszystkim z komisarzem do spraw pomocy humanitarnej i zarządzania kryzysowego oraz komisarzem do spraw handlu. Dla większej spójności działań zewnętrznych F. Mogherini będzie też przewodniczyć spotykającej się co najmniej raz w miesiącu Grupie do spraw Działań Zewnętrznych w ramach Komisji, a tym samym decydować o tematach podejmowanych na jej posiedzeniach [Lange 2014].

Działania F. Mogherini są zapewne związane z całkowicie odmienną interpretacją najważniejszego zadania stojącego przed Wysokim Przedstawicielem. W myśl Traktatu z Lizbony Wysoki Przedstawiciel zajmuje się trzema obszarami: WPZiB, WPBiO oraz spójnością działań zewnętrznych Unii Europejskiej. Każdy Wysoki Przedstawiciel indywidualnie decyduje o tym, ile czasu i uwagi poświęci poszczególnym obszarom. Jak dotąd Wysocy Przedstawiciele skupiali się na dwóch pierwszych aspektach - J. Solana na polityce bezpieczeństwa, a C. Ashton na polityce zagranicznej. Sądząc po pierwszych działaniach Federici Mogherini, postanowiła ona zająć się dotąd pomijanym aspektem spójności działań zewnętrznych UE. Już podczas przesłuchania przed Parlamentem Europejskim powiedziała, że to właśnie spójność działań stanowi klucz do pełnego wykorzystania potencjału zewnętrznego UE. Stwierdziła też, że nie ma takiej unijnej polityki, która nie byłaby powiązana z wymiarem zewnętrznym, dotyczy to zarówno polityki energetycznej, wewnętrznej, klimatycznej, rozwojowej, jak i wymiaru sprawiedliwości i polityki rozszerzeń [The Committe on Foreign Affairs 2014].

Innym zadaniem stojącym przed F. Mogherini jest zwiększenie efektywności pracy ESDZ i przeprowadzenie koniecznych zmian w jej strukturze. W tym celu Komisja Europejska zasugerowała, by Wysoka Przedstawiciel przed końcem 2015 roku dokonała przeglądu oraz oceny organizacji i funkcjonowania Europejskiej Służby Działań Zewnętrznych. Polepszenie organizacji pracy ESDZ stanowi ewidentnie jeden z priorytetów nowej Wysokiej Przedstawiciel, poświęciła temu zadaniu wiele uwagi w pierwszych miesiącach swojej pracy. Połączyła stanowiska Wykonawczego Sekretarza Generalnego i Dyrektora Operacyjnego, z Dyrekcji do spraw Polityki Bezpieczeństwa wydzieliła Dyrekcję do spraw Sankcji, a Dyrekcję Andyjską i Dyrekcję do spraw Mercosuru połączyła w nową Dyrekcję do spraw Ameryki Południowej. Ponadto Specjalni Przedstawiciele Unii Europejskiej zostali włączeni w struktury pod bezpośrednim zwierzchnictwem Wysokiego Przedstawiciela [Blockmans, Montesano 2015]. Te zmiany, mające na celu usprawnienie pracy ESDZ, nie są zapewne ostatnimi, jakie zaproponuje F. Mogherini, zwłaszcza że efektywne funkcjonowanie unijnej dyplomacji pozytywnie wpłynie na spójność działań zewnętrznych.

Ze względu na wspomniane już potrójne umocowanie oraz liczne zadania Wysokiego Przedstawiciela jego kalendarz jest wyjątkowo napięty. Ponadto sprawowanie tej funkcji wiąże się z zasiadaniem w licznych grupach i komitetach poświęconych problemom szeroko rozumianej polityki zagranicznej i bezpieczeństwa. Już w przypadku C. Ashton zauważono, że Wysokiemu Przedstawicielowi pośród wielu obowiązków brakuje czasu na uczestnictwo w spotkaniach 
wszystkich gremiów. Jednak dla spójności działań zewnętrznych Unii wskazana by była jego obecność. Pojawiły się pomysły, by wyznaczyć stałych przedstawicieli w konkretnych gremiach bądź też sformalizować istnienie tych powoływanych ad hoc [Cirlig 2014]. Jeśli F. Mogherini zamierza efektywnie wypełniać powierzoną jej funkcję, a przede wszystkim skupić się na spójności działań, będzie musiała wkrótce rozwiązać ten problem.

Oprócz indywidualnego zinterpretowania zadań stojących przed Wysokim Przedstawicielem, F. Mogherini będzie musiała także zadbać o sposób, w jaki jest postrzegana, zarówno na forum międzynarodowym, jak i wśród europejskich polityków i przywódców. Silna pozycja na obu płaszczyznach pozwoli jej nie tylko sprostać wygórowanym wymaganiom państw członkowskich, ale również zrealizować własne koncepcje i pomysły. Dyplomacja, zwłaszcza unijna, rządzi się specyficznymi prawami, a ich zrozumienie i umiejętne wykorzystanie są kluczowe dla osób na stanowiskach dających tak duże możliwości wpływu jak Wysoki Przedstawiciel. Poprzedniczce Mogherini, C. Ashton, zarzucano, że nie rozumie wagi symboli w polityce, a zwłaszcza w dyplomacji [Quatremer 2010]. Natomiast Mogherini przed objęciem urzędu, w kontekście amerykańskiej obecności w Europie jako symbolicznej gwarancji stabilności, otwarcie stwierdziła, że „nie powinniśmy tak bardzo koncentrować się na symbolach” [Manea, Solomon 2014]. Ashton w końcu zmieniła swoją politykę i doceniła wagę symboli. Czy teraz, gdy F. Mogherini sama stała się symbolem Unii Europejskiej na forum międzynarodowym, nauczy się wykorzystywać środki typowe dla dyplomacji i budować swoją pozycję w Europie i na świecie? Pozostaje jedynie mieć nadzieję, że Włoszka szybko nadrobi swoje braki w doświadczeniu, wynikające $\mathrm{z}$ bardzo krótkiego czasu, jaki spędziła, sprawując urząd ministra spraw zagranicznych.

W jednym aspekcie polityka F. Mogherini diametralnie różni się od stylu pracy jej poprzedniczki. Włoszka o wiele częściej występuje w mediach, chętnie udziela wywiadów i wypowiada się na tematy związane z polityką zagraniczną oraz bezpieczeństwem, wygłasza przemówienia na szczytach międzynarodowych i spotkaniach oraz publikuje swoje opinie w prasie, nie tylko włoskiej. Być może ze względu na to, że jest młodsza niż Ashton, znacznie lepiej rozumie też konieczność udzielania się w mediach społecznościowych. Mogherini i jej współpracownicy aktywnie prowadzą jej profil na portalach społecznościowych Facebook i Twitter, a aktualne zdjęcia i filmy dokumentujące pracę Wysokiej Przedstawiciel dostępne są za pośrednictwem fotograficznego serwisu społecznościowego Instagram oraz własnego kanału na portalu YouTube. Oficjalna strona internetowa ESDZ, która stanowi również oficjalną stronę Wysokiego Przedstawiciela, została rozbudowana, unowocześniona i dostosowana do urządzeń mobilnych. Znajduje się na niej znacznie więcej informacji niż tylko kalendarz spotkań Wysokiej Przedstawiciel i oficjalne wypowiedzi z konferencji prasowych, jak to miało miejsce za czasów C. Ashton. Obecnie publikowane są również wywiady z nową Wysoką Przedstawiciel i jej przemówienia ze szczytów i spotkań. 
Nie można jednak nie zauważyć, że F. Mogherini zdecydowanie unika kontrowersyjnych tematów, a jej wypowiedzi należą do wyjątkowo wyważonych i zachowawczych. Może to częściowo wynikać ze specyfiki funkcjonowania stanowiska Wysokiego Przedstawiciela, który stale musi zabiegać o poparcie ze strony państw członkowskich, a jakakolwiek radykalna wypowiedź spotkałaby się zapewne z ich zdecydowanym sprzeciwem. Sama F. Mogherini również nie słynie z otwartego wygłaszania swoich opinii i poruszania kwestii, które mogłyby wywołać dyskusję.

Tymczasem prawdopodobnie najważniejszym a zarazem najtrudniejszym zadaniem stojącym przed Federicą Mogherini będzie zbudowanie swojej pozycji w Europie i na świecie. Obejmując stanowisko Wysokiego Przedstawiciela, była osobą praktycznie nieznaną poza rodzimymi Włochami, nie liczyła się w światowej polityce, nie miała kontaktów na najwyższych politycznych szczeblach, a jej poglądów, nawet jeśli były komuś znane, nie brano pod uwagę. W ciągu pięciu lat, a dla dobra unijnej polityki zagranicznej nawet szybciej, Mogherini musi się stać charyzmatycznym politykiem i osobą kojarzoną z Unią Europejską, której głos będzie słyszany w międzynarodowej polityce. Można jedynie mieć nadzieję, że choć młodsza, ale bardziej doświadczona w polityce i zdecydowanie bardziej energiczna niż jej poprzedniczka, Mogherini szybko wdroży się w pracę Wysokiego Przedstawiciela i zaznaczy swoją pozycję na świecie.

\section{PODSUMOWANIE}

W czasie swojej pięcioletniej kadencji Federica Mogherini będzie musiała się zmierzyć z bardzo wieloma zadaniami. Wśród nich z jednym z najtrudniejszych, jakim będzie sprostanie wygórowanym i najczęściej sprzecznym ze sobą oczekiwaniom państw członkowskich. Oceniając cechy, które przesądziły o jej wyborze na stanowisko Wysokiego Przedstawiciela, państwa członkowskie niechętnie widziałyby w tej roli energicznego polityka, który byłby zdolny poprowadzić wspólną politykę zagraniczną i obrony według własnej wizji. Jednocześnie oczekują od osoby na tym stanowisku pełnego zaangażowania w swoją pracę, dużej aktywności na arenie międzynarodowej, nieustannych spektakularnych sukcesów oraz efektywnego rozwiązywania problemów, z którymi same państwa członkowskie nie są w stanie sobie poradzić. To wszystko powinno być możliwe do osiągnięcia przy jednoczesnym unikaniu jakichkolwiek działań, które mogłyby stać w sprzeczności z wolą któregokolwiek z dwudziestu ośmiu państw członkowskich oraz przy użyciu możliwie najniższych nakładów finansowych.

Wyraźnie widać, że wykonywanie zadań Wysokiego Przedstawiciela zgodnie z wyidealizowaną wizją państw członkowskich jest absolutnie niemożliwe. Jakkolwiek praca Federici Mogherini jest o tyle łatwiejsza, że ze względu na mnogość problemów, obejmujących zarówno WPZiB, jak i spoza niej, państwa członkowskie wręcz oczekują od Wysokiego Przedstawiciela wykazania się 
inicjatywą. Stanowi to niebagatelną szansę dla F. Mogherini na wprowadzenie w życie własnych pomysłów i koncepcji. Można jedynie mieć nadzieję, że z niej skorzysta, by tchnąc impuls w WPZiB, którego ta od lat potrzebuje.

Paradoksalnie na jej korzyść działa również miażdżąca krytyka pracy jej poprzedniczki C. Ashton. W związku z poszukiwaniem nowych rozwiązań i próbą usprawnienia pracy Wysokiego Przedstawiciela, państwa członkowskie wydają się bardziej chętne do zaakceptowania projektów przedstawionych przez Federicę Mogherini, a nawet do poszerzenia kompetencji sprawowanej przez nią funkcji.

Pięcioletnia kadencja Federici Mogherini z pewnością nie będzie należała do łatwych i spokojnych. Zadania, jakie przed nią stoją, to już nie zwyczajowe podtrzymywanie kontaktów politycznych z poszczególnymi regionami świata, promowanie unijnych wartości czy udział w niekończących się mediacjach w konfliktach, do których istnienia wszyscy już się przyzwyczaili. Wysoka Przedstawiciel będzie musiała zmierzyć się z zupełnie nowymi wyzwaniami, z realnym zagrożeniem tuż przy granicach Unii Europejskiej i w jej strefie wpływów. Będzie musiała wykazać się umiejętnością zarządzania kryzysami i dowieść, że potrafi myśleć nieszablonowo oraz rozwiązywać wiele problemów jednocześnie.

Naturalnie nie należy oczekiwać, że Mogherini zajmie się wszystkimi problemami i wszystkim poświęci tyle samo uwagi. Najprawdopodobniej, podobnie jak jej poprzednicy, wybierze jakąś dziedzinę działalności, w której będzie się najlepiej odnajdywała, i na niej skoncentruje swoją aktywność. Jak wykazano w niniejszym artykule, wybór ma ogromny, od kontynuowania mediacji w konfliktach, poprzez różne aspekty bezpieczeństwa, aż po kwestie instytucjonalne i efektywność działań ESDZ. Jak dotąd Wysoka Przedstawiciel najbardziej zaangażowała się w walkę z nielegalną imigracją, być może dlatego, że ten problem nie był jej obcy, jeszcze zanim objęła stanowisko. Z czasem okaże się, czy postanowi podjąć również inne zagadnienia z obszaru szeroko rozumianego bezpieczeństwa czy też, wdrożywszy się w pracę Wysokiego Przedstawiciela, zajmie się innymi wyzwaniami stojącymi przez Unią Europejską w obszarze WPZiB.

Nie można również zapominać o czekającym ją zadaniu usprawnienia pracy ESDZ i zapewnienia spójności działań zewnętrznych Unii Europejskiej. Jako że F. Mogherini poświęciła im pierwsze miesiące swojej pracy, można uznać, że uważa je za istotny element swojej kadencji. Uwzględniwszy jej dobre relacje z przewodniczącym Komisji Jeanem-Claude'em Junckerem, jej szanse na odniesienie sukcesu na tym polu są dość duże. Czy jednak przesunięcie ciężaru prac z ESDZ na Komisję nie spowoduje marginalizacji tego pierwszego?

Trudność zadania stojącego przed F. Mogherini wynika z faktu, że jej ewentualny sukces nie zależy jedynie od niej samej. Jeden z paradoksów jej pracy polega na tym, że do tego, aby mogła wykazać się pożądanymi przez państwa członkowskie znakomitymi efektami pracy, konieczna jest zgoda i współpraca państw członkowskich. Sama Wysoka Przedstawiciel może bowiem podejmować decyzje i inicjatywy w niewielkim zakresie, a większość jej pomysłów wymaga zgody państw członkowskich, która nierzadko jest trudna do zdobycia. W efek- 
cie F. Mogherini będzie mogła działać jedynie w zakresie, na jaki pozwolą jej państwa członkowskie, i w dużej mierze to od nich zależy, jaki przebieg będzie miała jej kadencja.

Obsadzając F. Mogherini w roli Wysokiego Przedstawiciela Unii do spraw Zagranicznych i Polityki Bezpieczeństwa, państwa członkowskie wykazały się raczej pragmatyzmem niż wizjonerstwem. Wśród proponowanych kandydatów nie brakowało osób z o wiele większym doświadczeniem, które prawdopodobnie lepiej poradziłyby sobie ze stojącym przed nią zadaniem. Jednak to właśnie Włoszka otrzymała stanowisko Wysokiego Przedstawiciela, i to ona musi sprostać wyzwaniu prowadzenia WPZiB wśród sprzecznych interesów państw członkowskich, meandrów dyplomatycznych zabiegów i nieprzejednanej krytyki ze strony innych polityków. To, czy poradzi sobie z tym zadaniem, zależy od tego, czy będzie w stanie zarówno zbudować sobie silną pozycję w ramach Unii, jak i współpracować z państwami członkowskimi i instytucjami UE. Jak zauważyła sama Mogherini podczas przesłuchania przed Parlamentem Europejskim, Wysoki Przedstawiciel posiada już wszystkie narzędzia niezbędne do osiągnięcia sukcesu - odpowiednie przepisy w Traktacie i ESDZ; jej zadaniem przez najbliższe pięć lat będzie użyć ich do zbudowania „wspólnej polityki”, „wspólnej wizji” i „wspólnej strategii" [The Committe on Foreign Affairs 2014]. Z pewnością najbliższe pięć lat będzie stanowiło dla niej okres ciężkiej i wytężonej pracy, której rezultaty będą miały znaczenie dla całej Unii.

\section{WYKAZ PIŚMIENNICTWA}

1. Blockmans S., Montesano F.S., 2015: Mogherini's first 100 days: Not the quiet diplomat.

2. Cirlig C.-C., 2014: Federica Mogherini. High Representative of the Union for Foreign Affairs and Security Policy / Vice-President of the Commission. Hearings of European Commissioners - designate, European Parliamentary Research Service, 6.

3. The Committee on Foreign Affairs, 2014: Hearing of Federica Mogherini Vice-President-Designate of the Commission, High Representative of the Union for Foreign Affairs and Security Policy, Brussels, 5.

4. Đorđević V.V., Malazogu L., Nič M., Ejdus F., 2014: Mogherini’s Chance for True Rapprochement between Serbia and Kosovo, Central European Policy Institute.

5. Komisja Europejska: http://ec.europa.eu/commission/2014-2019/mogherini_en, [dostęp: 4 sierpnia 2015].

6. Lange S., 2014: HR/VP to VP/HR? The next generation, ISSUE Brief 30/2014, 3.

7. Malantowicz A., Smalec Ł. (red.), 2014: Stabilizacja i destabilizacja?: społeczność międzynarodowa wobec programu nuklearnego Iranu, Wyd. WDiNP UW, Warszawa.

8. Manea O., Solomon S., 2014: Cine va conduce politica externă a UE?, Revista 22.

9. Mogherini F., 2015: The Iran agreement is a disaster for Isis, The Guardian.

10. EurActive.com, 2014: Mogherini: Russia is no longer the EU's strategic partner, http://www. euractiv.com/sections/global-europe/mogherini-russia-no-longer-eus-strategic-partner-308152, [dostęp: 04.08.2015]. 
11. Nünlist Ch., 2015: EU Foreign Policy: Mogherini Takes Over, CSS Analyses in Security Policy No. 167, 4.

12. Panichi J., 2014: Federica Mogherini - Italy's scapegoat, Politico, aktualizacja z dn. 29.01.2015.

13. Quatremer J., 2010: Ashton ne répond plus au téléphone européen après 20 heures, Coulisses de Bruxelles, http://bruxelles.blogs.liberation.fr/coulisses/2010/01/ashton-ne-r\%C3\%A9pondplus-au-t\%C3\%A91\%C3\%A9phone-europ $\% \mathrm{C} 3 \% \mathrm{~A} 9 \mathrm{en}-\mathrm{apr} \% \mathrm{C} 3 \% \mathrm{~A} 8 \mathrm{~s}-20$-heures.html, [dostep: 04.08.2015].

14. Redei L., 2014: Weak and Weaker, Foreign Affairs.

15. Toscano R., 2014: Mogherini Challenge, Opinión Europa 263, 1.

THE EXPERIENCE OF CATHERINE ASHTON AS A CHALLENGE FOR FEDERICA MOGHERINI

\begin{abstract}
This article aims to analyse the challenges faced by Federica Mogherini as the European Union's High Representative for Foreign Affairs and Security Policy in relation to the problems Catherine Ashton tackled. It also identifies the specific tasks for Mogherini within the CFSP, including issues about implementing the functions of the High Representative. This will determine the nature of the Mogherini term and the likely direction of the changes she introduces.
\end{abstract}

Key words: Federica Mogherini, High Representative, the High Representative of the Union for Foreign Affairs and Security Policy, common foreign and security policy, Catherine Ashton 